\title{
Os Anjos da Meia-Noite: trabalhadores, lazer e direitos no Rio de Janeiro da Primeira República
}

\author{
Leonardo Affonso de Miranda Pereira[1]
}

\begin{abstract}
Resumo
Em julho de 1913, os sócios do Club Dançante Familiar Anjos da Meia Noite requeriam ao Supremo Tribunal Federal um habeas corpus que lhes garantisse o direito de realizar bailes dançantes na região portuária do Rio de Janeiro. Era o fim de uma longa batalha jurídica por meio da qual os trabalhadores de baixa renda que compunham o clube, em sua maioria negros e mestiços, tentavam assegurar seus direitos recreativos. O faziam, porém, a partir de um tipo de associação cujos objetivos estavam distantes da lógica própria ao movimento operário do período. Acompanhar o caso, dando a ver seus antecedentes e lógicas, é, por isso, um meio de refletir sobre a imagem passiva projetada sobre os trabalhadores do Rio de Janeiro na Primeira República por parte da historiografia.
\end{abstract}

Palavras-chave: trabalhadores; lazer; cidadania.

Los Anjos da Meia Noite: trabajadores, ocio y derechos en Río de Janeiro de la Primera República

\section{Resumen}

En julio del año 1913, los miembros del Club de Baile Familiar Anjos da Meia Noite presentaron a la Corte Suprema un recurso de habeas corpus que les garantizaba el derecho de realizar sus bailes en la zona portuaria de Río de Janeiro. Era el final de una larga batalla legal en que los trabajadores de bajos ingresos del club, en su mayoría negros y mestizos, trataron de proteger sus derechos al entretenimiento. Lo hicieron, sin embargo, en una asociación cuyos objetivos estaban lejos de la lógica del movimiento obrero de la época. Analizar el caso, mostrando su lógica, es por lo tanto una manera de reflexionar sobre la imagen pasiva de los trabajadores del Rio de Janeiro de la Primera República proyectada por parte de la historiografía.

Palabras clave: trabajadores; ocio; ciudadanía.

Anjos da Meia Noite: Work, leisure and rights in the Rio de Janeiro of the First Republic

Abstract

In July 1913, the members of the Family Dancing Club Anjos da Meia Noite required a habeas corpus to the Supreme Court to secure their right to perform dancing parties in the port area of Rio de Janeiro. It was the end of a long legal battle, through which the low-income workers who were part of the club, mostly the Blacks and Mestizos, tried to maintain their recreational rights. They did so, however, from a kind of association whose objectives were far from the logic of the labor movement at the time. Tracking the case, analyzing its background and logic, is a way of reflecting on the passive image projected on the Rio de Janeiro's workers of the First Republic by the historiography.

Keywords: workers; leisure; citizenship.

Les Anges de Minuit: le travail, les loisirs et les droits au Rio de Janeiro de la Première République

\section{Résumé}

En Juillet 1913, les membres du Club de Danse de la Familie Les Anges de Minuit ont demandé à la Cour suprême un habeas corpus pour leur garantir le droit à exécuter des danses dans la zone portuaire du Rio de Janeiro. C'était la fin d'une longue bataille juridique menée par les travailleurs à faible revenu qui ont participé au club, surtout les noirs et les métis, pour assurer leur droits à les loisirs. Cela a été fait à partir d'une sorte d'association dont les objectifs étaient distants de la logique du mouvement ouvrier de lépoque. Suivre l'affaire, en expliquant son origine et sa logique, c'est une façon de réfléchir sur l'image passive qui est resté des travailleurs de Rio de Janeiro dans la Première République du point de vue de l'historiographie. Mots-clés: travailleurs; les loisirs; citoyenneté. 

um processo diferente daqueles que costumavam alcançar a mais alta Corte do país. Os sócios do Club Dançante Familiar Anjos da Meia Noite requeriam, por meio de seu advogado, um habeas corpus que lhes garantisse o direito de continuar a realizar bailes e outras atividades recreativas na Saúde, região portuária do Rio de Janeiro. Frente a uma situação na qual o clube estaria "constrangido, violentamente, pelo Sr. Dr. Chefe de Polícia a não funcionar" desde que ele mandara fechar sua sede e cassar sua licença de funcionamento, alegavam que, com a proibição, o clube deixaria "de existir", sendo "extinto e dissolvido". ${ }^{1}$ Respaldados pelas determinações da Lei promulgada em 1893 para regular "a organização das associações que se fundarem para fins religiosos, morais, científicos, artísticos, políticos ou de simples recreio", na qual se reconhecia a possibilidade de personalidade jurídica de associações como aquela, ${ }^{2}$ apresentavam-se ao tribunal para defender a sobrevivência e liberdade do clube.

Tratava-se, para os próprios contemporâneos, de uma ação inusitada, definido pelo jornal $A$ Noite como "um pedido original.". O primeiro motivo do estranhamento ligava-se ao fato de que o requerente do habeas corpus era não uma pessoa física, cuja liberdade ou vida estivesse ameaçada, como de costume, mas uma sociedade civil. Não era apenas esse, no entanto, o motivo do estranhamento. Junto a questões ligadas às normas processuais, o caso mostrava-se também singular frente ao perfil do solicitante, um simples clube recreativo. Fundado em $1^{\circ}$ de julho de 1906, ele tinha, segundo seus estatutos, a finalidade de "dar bailes, pelo menos uma vez por mês aos seus sócios, convidados e famílias destes"; "ensinar os seus sócios a dançar", mantendo " uma aula de dança para o ensino de seus sócios"; e de "divertir por todos os meios morais e lícitos" seus componentes. ${ }^{4}$ Ligado à simples busca do prazer e da diversão de seus membros, o clube mostrava-se distante de qualquer objetivo de representação social ou luta política, afastando-se, com isso, das questões usualmente analisadas pela Corte suprema do país.

Uma terceira questão, por fim, explicaria a surpresa dos contemporâneos ante o pedido levado ao Supremo Tribunal pelos sócios do Anjos da Noite: o perfil social e étnico de seus componentes. Este evidencia-se nas profissões de seus diretores, informadas ao Chefe de Polícia em 1912 no momento em que o clube requeria a licença anual de funcionamento. Apresentavam-se um ladrilheiro, um operário do Arsenal da Marinha, um trabalhador da Light e um estivador do cais do porto, que era o presidente do clube. ${ }^{5}$ Semelhante era o tipo de atividade de seus fundadores, dentre os quais foi possível identificar trabalhadores braçais como Cesar Neves de Carvalho, um cocheiro, e David Francisco Carvalho, foguista. ${ }^{6}$ Atento a essa composição socialmente definida,

\footnotetext{
1Arquivo Nacional. Fundo Supremo Tribunal Federal (BV). BV.4624. - Série Habeas Corpus - Clube Dançante Familiar Anjos da Meia Noite (1913), fl.12.

2“Lei no 173, de 10 de Setembro de 1893”, In: Coleção de Leis do Brasil - 1893, vol. 1, p. 45. Disponível em: <http:// www2.camara.leg.br/legin/fed/lei/1824-1899/lei-173-10-setembro-1893-540973-publicacaooriginal-42519-pl. html>. Acesso em: 15 out. 2013.

3“Um pedido original", A Noite, 5 de julho de 1913.

4“Sociedades civis - Club Dançante Familiar Anjos da Meia Noite”, Diário Oficial, 10 de março de 1910, p. 1786. ${ }^{5}$ Arquivo Nacional, GIFI 6C 432.

${ }^{6}$ Cf. "Encontro de veículos", A Noite, 25 de julho de 1912; e "Centro Geral dos Foguistas", Correio da Manhã, 29 de março de 1904. A lista com os nomes dos fundadores encontra-se nos estatutos publicados em "Sociedades civis - Club Dançante Familiar Anjos da Meia Noite", Diário Oficial, 10 de março de 1910, p. 1786.
} 
um redator do Jornal do Brasil, em uma de suas notícias sobre os Anjos da Meia Noite, os definia como uma sociedade "onde se reúne a fina flor da gente que se diverte com pouco dinheiro"?

Em uma sociedade recém-egressa da escravidão, na qual negros e pardos constituíam ainda a maior parte da força de trabalho, não é de se admirar que fossem em sua maior parte de ascendência africana os componentes do grupo. Longe de ser um detalhe, essa marca étnica estava na própria base da identidade construída pelos sócios do clube. Não por acaso, naquele mesmo ano de 1913, no dia em que se comemoravam os 25 anos da abolição da escravidão, a sua diretoria publicou um anúncio nos jornais divulgando "um grande baile de kermesse" em "regozijo à festa de 13 de maio", feita a "pedido dos nossos frequentadores deste club (sic)".

Se tais fatores explicam por que os próprios contemporâneos estranharam o pedido apresentado pelos sócios do clube ao Supremo Tribunal Federal, mais incompreensível ainda parece tal solicitação à luz de parte da historiografia sobre o período. A partir da década de 1930, intelectuais ligados ao projeto político do chamado Estado Novo trataram de definir, para as primeiras décadas da República, uma marca oligárquica e excludente, na qual inexistiria qualquer espaço de ação ou participação para os trabalhadores. ${ }^{9}$ A partir da suposição da incapacidade de ação coletiva da massa de trabalhadores nacionais, em grande parte decorrente de sua recente condição escrava, formulou-se para o período a imagem de uma completa ausência de participação política.

Cristalizada pela historiografia das décadas posteriores sob a designação de "República Velha", ${ }^{10}$ tal leitura foi rechaçada por trabalhos mais recentes que apontam para seu caráter teleológico. Ainda assim, permanece por vezes em algumas análises a crença na completa impossibilidade de participação política dos trabalhadores no período. Em artigo que retoma argumentos já esboçados em trabalhos anteriores, José Murilo de Carvalho defende que, no início do século XX, "as oligarquias conseguiram inventar e consolidar um sistema de poder capaz de gerenciar seus conflitos internos que deixava o povo de fora". ${ }^{11}$ A partir da engenharia política formulada por Campos Salles e sua política dos governadores, teria assim se firmado um sistema de poder que garantia a estabilidade da República, excluindo qualquer possibilidade de cidadania para os trabalhadores.

Como resultado, as únicas possibilidades de manifestação efetiva do povo ao longo da Primeira República se dariam "à margem dos mecanismos formais de participação, quando não contra o próprio sistema político". Era o que ocorria em greves operárias capitaneadas por trabalhadores imigrantes, cujo efeito sobre o sistema político "foi limitado" pela dificuldade de que tais movimentos pudessem "influenciar a política via participação eleitoral"; ou em revoltas de "caráter defensivo" promovidas por um universo mais amplo de trabalhadores pobres: o "povo da rua", que reagia em motins, como a Revolta da Vacina

7“Quem não trouxe... - Depois do baile - Ciúme sanguinário", Jornal do Brasil, 26 de maio de 1913. 8“S.D.F. Anjos da Meia Noite", Jornal do Brasil, 13 de maio de 1913.

${ }^{9}$ Acompanho, nesse parágrafo, as observações feitas por Ângela de Castro Gomes e Martha Abreu na "Apresentação" ao dossiê “A Nova Velha República”, Tempo, n. 26, jan. 2009, p. 1-14.

${ }^{10} \mathrm{Cf}$. Edgard Carone, A República Velha (Instituições e classes sociais), São Paulo, DIFEL, 1970

"José Murilo de Carvalho, "Os três povos da República", Revista USP, n. 59, set.-nov. 2003, p. 96. Ver, ainda, Idem, Os bestializados. O Rio de Janeiro e a República que não foi, São Paulo, Companhia das Letras, 1987. 
ou a Revolta da Chibata, à "ingerência do Estado, considerada ilegítima, em suas vidas". Configurava-se, assim, a "incapacidade do regime de incorporar o povo da rua, o povo politicamente ativo".12

Verdadeira para todos os trabalhadores, tal exclusão seria ainda mais marcante no caso dos negros e pardos - cujos costumes e tradições, alvos preferenciais da vigilância republicana, teriam sido de todo marginalizados no período. A partir dos ditames da lógica cientificista, que passava a justificar as ações dos governos republicanos, ${ }^{13}$ esses sujeitos teriam se transformado em vítimas preferenciais do novo regime, que tentava apagar suas marcas da imagem projetada para a nação. Nesse quadro, só restaria a eles tentar reagir defensivamente a essa tentativa de apagamento, em uma atitude de simples resistência por meio da qual evidenciariam sua aversão à nova ordem política. ${ }^{14}$ Da soma entre uma ordem institucional oligárquica e excludente e os ditames de uma ideologia cientificista que justificava tal exclusão, definia-se, em tais análises, a imagem de uma belle époque republicana branca e cosmopolita, ${ }^{15}$ que teria esmagado de todo a crescente aspiração de ex-escravos e seus descendentes por novos direitos.

Corretas, se pensadas de uma perspectiva puramente eleitoral, tais leituras iluminam o modo pelo qual se estruturou a ordem republicana do ponto de vista daqueles que comandavam seus mecanismos. Ainda assim, elas acabam por desconsiderar a possibilidade de existência de outras formas de participação política que se estruturavam por dentro dessa ordem republicana. ${ }^{16}$ É o caso, em especial, das que adotavam lógicas e formas de ação diversas daquelas das lideranças letradas ou dos trabalhadores de origem europeia. Ao analisar o caso dos muitos trabalhadores escravizados durante o Império, estudos desenvolvidos a partir da década de 1980 mostraram a parcialidade das análises que pensavam os cativos como simples objetos passivos da vontade e da ação senhorial. Voltados para a experiência de tais sujeitos, análises como as de Sidney Chalhoub, João José Reis e Maria Helena Machado iluminavam a lógica própria que alimentava cotidianamente sua atuação. Em conjunto, indicavam que, ainda que por caminhos diferentes daqueles forjados no mesmo período pelos trabalhadores europeus, escravos e homens livres de cor afirmavam sua própria forma de luta, por vezes construída por dentro

12José Murilo de Carvalho, "Os três povos da República", Revista USP, n. 59, set.-nov. 2003, p. 107-110. Sobre a lógica oligárquica da política dos governadores implementada por Campos Salles, ver ainda Maria Efigênia Lage de Resende, "O processo político na Primeira República e o liberalismo oligárquico", In: Lucília de Almeida Delgado; Jorge Ferreira (orgs.), O tempo do liberalismo excludente. Da Proclamação da República à Revolução de 1930, Rio de Janeiro, Civilização Brasileira, 2003, p. 89-120.

${ }^{13}$ Cf. Oswaldo Porto Rocha, A Era das Demolições: cidade do Rio de Janeiro 1870-1920, Rio de Janeiro, Secretaria Municipal de Cultura, 1986; e Sidney Chalhoub, Cidade febril: cortiços e epidemias na Corte imperial, São Paulo, Cia da Letras, 1996.

${ }^{14}$ Conferir, por exemplo, Nicolau Sevcenko, A Revolta da Vacina: mentes insanas em corpos rebeldes, São Paulo, Brasiliense, 1983; e Raquel Soihet, A subversão pelo riso, Rio de Janeiro, Fundação Getúlio Vargas, 1998. ${ }^{15} \mathrm{Cf}$. Jeffrey Needell, Belle Époque Tropical. Sociedade e cultura de elite no Rio de Janeiro na virada do século, São Paulo, Cia das Letras, 1993.

${ }^{16}$ Nos dizeres de Ângela de Castro Gomes e Martha Abreu, "podemos afirmar que ainda se desconhece, basicamente por falta de estudos, uma rica movimentação de atores - intelectuais, trabalhadores, setores de classes médias e populares - empreendida no campo da participação política, que alcançou desenhos variados e mais ou menos formalizados em instituições e associações muito variadas", In: "Apresentação" ao dossiê “A Nova Velha República”, Tempo, n. 26, jan. 2009, p. 4. 


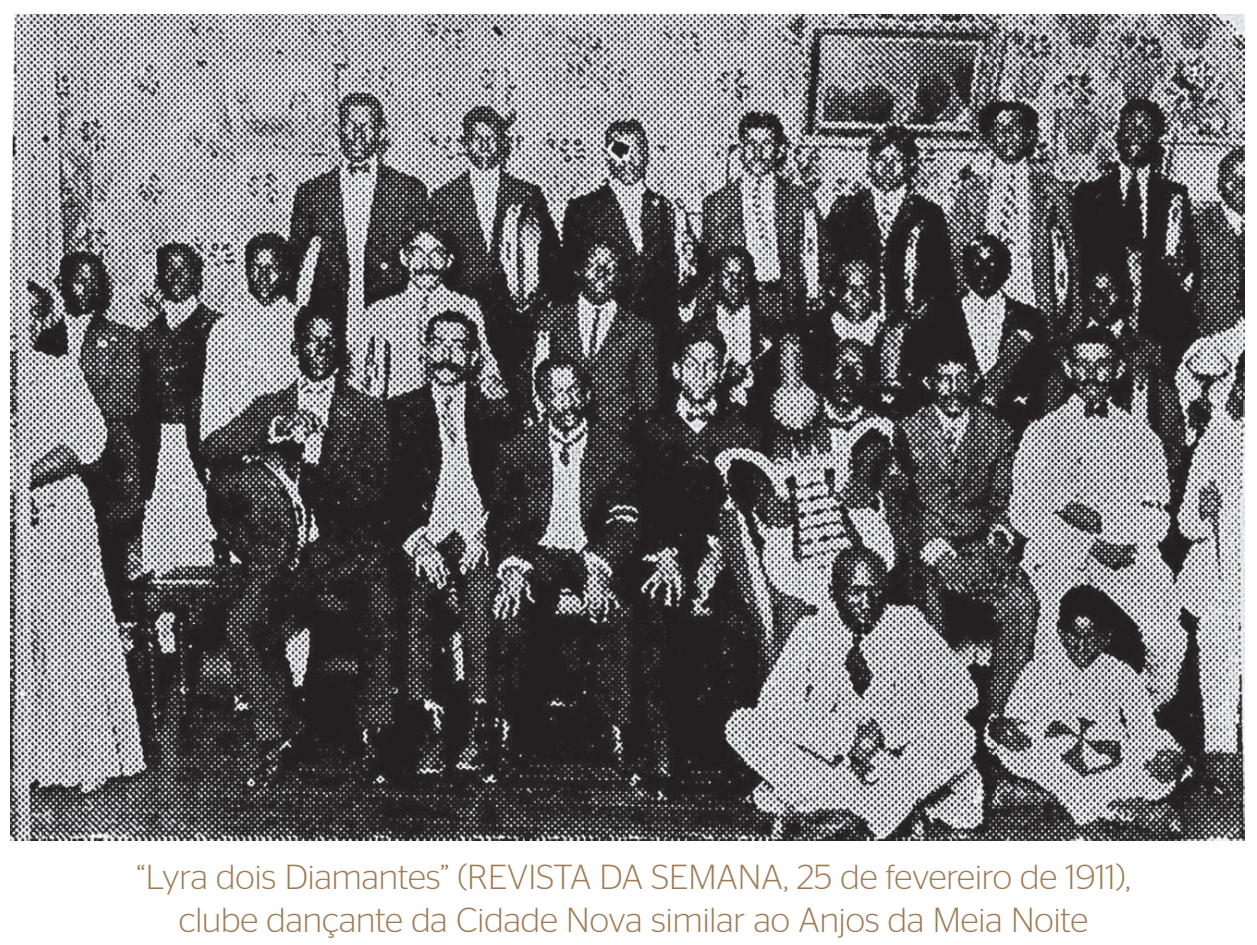

das redes do paternalismo. ${ }^{17}$ Sem atentar para as lógicas próprias que alimentavam essas formas de luta e articulação, só restava aos autores que tentaram entendê-los nos primeiros tempos da República atribuir a eles uma postura defensiva, simples negação da nova ordem.

Como resultado, definiu-se uma lacuna profunda na compreensão sobre as experiências dos trabalhadores negros e pardos entre o final do Império, momento no qual os escravos e homens livres de cor lutaram de formas diversas contra a dominação à qual estavam submetidos, e os anos 1930 do século $\mathrm{XX}$, quando seus costumes e práticas seriam finalmente incorporados, pelo menos formalmente, a uma nova configuração da nacionalidade. Ao ignorar qualquer possibilidade de agência dos trabalhadores em meio ao tal processo, muitos daqueles que analisaram a formulação de um novo perfil para a cultura brasileira a partir do final da década de 1920 trataram de tomá-lo como simples fruto da dádiva do Estado Novo ou da "descoberta" dos intelectuais, que passaram a valorizar essa marca popular e mestiça da nação ${ }^{18}-$ em interpretação que novamente relegava os trabalhadores negros e pardos ao papel de simples coadjuvantes.

\footnotetext{
${ }^{17}$ Conferir, entre outros, João José Reis; Eduardo Silva, Negociação e conflito: a resistência negra no Brasil escravista, São Paulo, Companhia das Letras, 1989; Sidney Chalhoub, Visões da Liberdade: uma história dos últimos anos da escravidão na Corte, São Paulo, Companhia das Letras, 1990; e Maria Helena P.T. Machado, O plano e o pânico, São Paulo/Rio de Janeiro, EDUSP/EDUERJ, 1994.

${ }^{18 V}$ Ver, por exemplo, José Adriano Fenerick, Nem do Morro Nem da Cidade: as transformações do samba e a indústria cultural. 1920-1945, São Paulo, Annablume, 2005 e Florencia Garramuño, Modernidades primitivas. Tango, samba e nación, Buenos Aires, Fondo de Cultura Económica, 2007.
} 
Na tentativa de fugir de tal armadilha, alguns estudos trataram de apontar para a necessidade de levar em conta a importância que tiveram, em meio a esse processo, os costumes e práticas compartilhados por homens e mulheres negros e pardos nas décadas anteriores. Ao percebê-las como objetos de interesse do mundo letrado desde o final do século XIX, ${ }^{19}$ mostravam que o estudo das práticas culturais desses trabalhadores afrodescendentes configurava-se como um meio de vê-los como sujeitos ativos dessa história. ${ }^{20}$ Em geral, entretanto, esses estudos têm por foco questões distantes da reflexão sobre a cidadania e a política formal, voltando-se preferencialmente para eventos recreativos como festas, músicas e bailes. Se nessas configuravam-se a força e a vitalidade de costumes e experiências que viriam a servir de base para a nova imagem da nacionalidade forjada nas décadas seguintes, resta ainda tentar entender o papel que tais práticas culturais desempenharam frente a uma estrutura política forjada para excluir os sujeitos que as promoviam.

Ao apelarem ao Supremo Tribunal Federal na tentativa de resguardar seus direitos recreativos e associativos, os sócios do Anjos da Meia Noite nos dão, assim, a chance de analisar, sob nova perspectiva, o sentido assumido naquele momento por costumes recreativos fundamentais na experiência de homens e mulheres aos quais se costuma negar qualquer possibilidade de ação. Estudos como o de Maria Cecília Velasco Cruz já se encarregaram de mostrar como esses trabalhadores marcados pela ascendência africana gestaram, nos primeiros tempos da República, formas próprias de articulação política, expressas nas disputas sindicais entre os estivadores cariocas. ${ }^{21}$ Seguindo essa trilha, resta acompanhar o caso dos Anjos da Noite, em seus antecedentes e lógicas, de forma a tentar entender como esses sujeitos se pensavam no período como cidadãos — ou seja, o modo pelo qual, a partir de suas práticas recreativas cotidianas, interagiam com uma nova ordem institucional por eles experimentada, em uma relação a partir da qual tentavam definir seu lugar na nação republicana que se gestava.

\section{Nos sambas da Saúde}

Quando alguns moradores do bairro da Saúde resolveram, em $1^{\circ}$ de julho de 1906, fundar o Club Dançante Familiar Anjos da Meia Noite, estavam longe de

\footnotetext{
19Martha Abreu; Carolina Dantas, "Música popular, folclore e nação no Brasil, 1890-1920", In: José Murilo de Carvalho (org.), Nação e cidadania no Império: novos horizontes, Rio de Janeiro, Civilização Brasileira, 2007. p. 123-151; Antonio Herculano Lopes, “Vem cá mulata!”, Tempo, vol. 26, jan. 2009, p. 80-100; e Carolina Vianna Dantas, "A nação entre sambas, cordões e capoeiras nas primeiras décadas do século XX”, ArtCultura, vol. 13, 2011, p. 85-102.

${ }^{20} \mathrm{Cf}$. Tiago de Melo Gomes, "Para além da casa da Tia Ciata: outras experiências no universo cultural carioca (1830-1930)", Afro-Ásia, vol. 29-30, 2004, p. 175-198; Martha Abreu, "Sobre mulatas orgulhosas e crioulos atrevidos: conflitos raciais, gênero e nação nas canções populares (sudeste do Brasil, 1890-1920)", Tempo, vol. 16, Rio de Janeiro, 2004, p. 143-174; Maria Clementina Pereira Cunha, "Não me ponha no xadrez com esse malandrão". Conflitos e identidades entre sambistas no Rio de Janeiro, início do século XX", Afro-Ásia, vol. 38, 2009, p. 179-210; e Leonardo Pereira, "O Prazer das Morenas: bailes, ritmos e identidades nos clubes dançantes da Primeira República", In: Andrea Marzano; Victor Andrade de Melo (orgs.), Vida Divertida: histórias do lazer no Rio de Janeiro (1830-1930), Rio de Janeiro, Apicuri, 2010, p. 275-299.

${ }^{21}$ Maria Cecília Velasco Cruz, "Da tutela ao contrato: 'homens de cor' brasileiros e o movimento operário carioca no pós-abolição", Topoi, vol. 11, n. 20, jan.jun. 2010, p. 114-135.
} 
ser originais. Até fevereiro daquele ano, pelo menos outros 60 grupos do gênero já tinham conseguido, junto ao chefe de polícia do Distrito Federal, sua licença de funcionamento - número que chegaria a $146 \mathrm{em} \mathrm{1912,} \mathrm{na} \mathrm{mostra} \mathrm{da} \mathrm{força}$ que ganhava o associativismo dançante na cidade. ${ }^{22}$ Os fundadores da associação somente se somavam assim a um fenômeno que, iniciado ainda na última década do século XIX, em poucos anos havia tomado conta de toda a cidade: a febre dançante. "O Rio de Janeiro é a cidade que dança", afirmava o poeta Olavo Bilac em crônica publicada na prestigiada revista Kosmos, poucas semanas antes de sua fundação. ${ }^{23}$ Surpreso com a proliferação de clubes dançantes por todos os bairros da capital federal, mostrava-se impressionado pelo entusiasmo causado por esse fenômeno - que fazia da dança, na cidade, "mais do que um costume ou um divertimento: é uma paixão, uma mania, uma febre".

Por mais que fizesse questão de afirmar o entusiasmo pela dança como “uma preocupação característica da vida carioca”, nem por isso Bilac deixava de apresentar as peculiaridades do modo pelo qual ela era vivida por diferentes sujeitos. Para ele, "estudando e classificando, por ordem de bairros, as danças preferidas do nosso povo", seria possível "estabelecer a geografia moral da cidade". "Botafogo não dança como o Catumbi, a Tijuca não dança como a Saúde", explicava, na crença de que "cada bairro tem a sua dança, que é a sua fisionomia característica, rigorosa e inconfundível”. Mostrava-se, dessa forma, atento às peculiaridades que separavam os eventos dançantes dos bairros elegantes daqueles que via nos subúrbios e nas regiões pobres. Em Botafogo, a dança seria "serena e majestosa como um rito religioso", com "cavalheiros severos" trajando casacas negras e gravatas brancas. Já na Saúde, essas tradições dançantes de origem europeia viriam a se misturar, de forma clara, a outras influências musicais até então ausentes dos bailes requintados:

Na Saúde, a Dança é uma fusão de danças, é o samba, - uma mistura do jongo e dos batuques africanos, do canaverde dos portugueses, e da poracé dos índios. As três raças fundem-se no samba, como num cadinho. O samba é a opoplocia do cortiço, é a pírrica da Estalagem. [...] Nele, desaparece o conflito das raças. Nele se absorvem os ódios da Cor. O Samba é - se me permitis a expressão - uma espécie de bule, onde entram, separados, o café escuro e o leite claro, e de onde jorra, homogêneo e harmônico, o híbrido café com leite.

Contrapostos à imagem europeizada dos salões dançantes dos bairros mais ricos da cidade, a marca dos bailes organizados no bairro em que apareceram os Anjos da Meia Noite seria a força que tinham ali costumes dançantes de suposta origem africana ou indígena. Essa singularidade marcava, ao mesmo tempo, a ligação dos bailes da Saúde com o fenômeno mais geral que via pela cidade e a sua singularidade, moldada por essa marca cultural particular. Como

${ }^{22}$ Cf. "Carnaval - Os clubes e grupos licenciados", Gazeta de Notícias, 10 de fevereiro de 1906; e Arquivo Nacional, GIFI 6C 377.

${ }^{23}$ Fantasio (Olavo Bilac), "A dança no Rio de Janeiro", Kosmos, Ano 3, n. 5, Maio de 1906. 
resultado, formava-se nos pequenos salões do bairro um tipo de dança forte e original, que já não se misturava com as tradições dançantes particulares a partir das quais ela havia sido criada.

Bilac tratava, porém, de um fenômeno socialmente determinado. Por mais que aponte para a mistura harmônica de tradições como caminho para superação dos "ódios da Cor" no bairro, ele mostra consciência de que, àquela altura, esse processo era próprio de um grupo social bem delimitado, muito presente na vida do bairro: os trabalhadores de baixa renda que viviam em cortiços e estalagens, como havia aos montes na Saúde. Eram eles que teriam no samba a dança característica com a qual combatiam os oponentes, como a opoplocia ou a pírrica dos gregos. ${ }^{24}$ Era assim como um fenômeno ligado ao mundo dos trabalhadores da Saúde, capaz de definir-lhes a identidade, que o cronista tratava dos ritmos gestados nos bailes do bairro.

\section{Enquanto o samba teria sua "origem na dança dos sertões da África Central", o baile seria "muito mais suave": "dança-se de vagar, ao som de um flautime de um cavaquinho"}

Não parecia casual, por isso, a citação dessas danças de combate na crônica de Bilac. Ao utilizá-las para se referir ao modo de dançar dos trabalhadores pobres da Saúde, Bilac podia ter em mente os frequentes embates sociais e culturais decorrentes do choque entre seus costumes e práticas e os comportamentos dele esperados por parte dos ideólogos da nova nação republicana. É o que ele mesmo pode ter testemunhado, de forma trágica, menos de dois anos antes, no momento da Revolta da Vacina. Na ocasião, a Rua Camerino, que serviria de sede aos Anjos da Meia Noite, foi tomada por trincheiras formadas "com sacos de areia, paralelepípedos e pedaços de pau", atrás das quais os trabalhadores do bairro defenderam como podiam suas práticas de cura tradicionais ameaçadas pelo projeto de vacinação obrigatória. ${ }^{25} \mathrm{Com}$ a possível lembrança do episódio, Bilac mostrava ver no samba dos bailes da Saúde uma prática cultural capaz de marcar uma identidade bem delimitada entre os trabalhadores do bairro, cujo sentido de perigo não parecia lhe escapar.

A referência de Bilac à especificidade do bairro da Saúde seria bem compreendida por qualquer contemporâneo. Apesar da inusitada citação às danças

${ }^{24} \mathrm{~A}$ opoplocia e a pírrica são danças militares da Grécia antiga. Cf. Encyclopédie militaire et maritime par le Comte de Chesnel, vol. 1. Paris, Le Chevalier, 1864 ; e G. Desrat, Dictionnaire de la danse, historique, théorique, pratique et bibliographique, Paris, Imprimeries Réunies, 1895, p. 260.

${ }^{25 " A}$ revolta dos alunos militares - Gravíssimo - Os fatos de ontem - Na Saúde", Gazeta de Notícias, 15 de novembro de 1904. Sobre a ligação entre a revolta e a força das heranças culturais africanas no bairro, ver Leonardo Pereira, Barricadas da Saúde. Vacina e protesto popular no Rio de Janeiro da Primeira República, São Paulo, Perseu Abramo, 2002. 
indígenas, a região da Saúde era conhecida no período por contar com uma presença especialmente forte de trabalhadores negros e pardos. Constituídos ao redor do cais do porto, os bairros da Saúde e da Gamboa abrigavam um grande contingente de estivadores - profissão na qual os trabalhadores de ascendência africana tinham clara primazia. Apesar da massiva chegada de imigrantes europeus à cidade desde as últimas décadas do século XIX, o porto continuava a congregar majoritariamente trabalhadores nacionais, o que permitia que houvesse ali "uma forte linha de continuidade entre os escravos e os libertos dos velhos tempos imperiais e os proletários da primeira República". ${ }^{26}$

Não era um acaso, por isso, que fosse naquela região que mais aparecessem, no período, notícias referentes à prática de batuques e candomblés. Ainda que estivesse longe de se restringir a um bairro específico, fazendo-se notar por toda a cidade, a crença na religião dos orixás tinha nessa região seu principal reduto. Ainda em 1886, Mãe Aninha havia fundado no bairro seu terreiro, iniciando uma proliferação de casas de santo na região. ${ }^{27}$ Em crônica publicada em 1904 na Gazeta de Notícias a respeito das práticas religiosas no Rio de Janeiro, João do Rio nomeia inúmeros outros terreiros que tinham ali sua sede. ${ }^{28}$ Por mais que a zona portuária fosse habitada também por diversos outros grupos de imigrantes ou brancos pobres, a presença intensa desse tipo de manifestação de costumes e práticas de matriz africana era uma de suas marcas principais.

Ao lado das manifestações religiosas, desenvolveram-se também, na região, práticas festivas e dançantes associadas pelos próprios contemporâneos às heranças africanas. Em 20 de dezembro de 1886, uma nota paga publicada no jornal O Paiz chamava a atenção da polícia para uma casa, situada nos fundos de uma estalagem, "onde reinam continuamente grandes batuques, que incomodam vizinhos e vão muito além das 10 horas da noite". ${ }^{29}$ Ainda que proibidos pelo Código de Posturas Municipais, "batuques e tocatas de pretos" como esses eram comuns em toda a região, que envolvia ainda os bairros da Saúde, Santana e Gamboa, conforme mostrava em 1866 a denúncia apresentada por um fiscal à Câmara Municipal. ${ }^{30}$ Chamados de batuques pela força que os instrumentos de percussão tinham nelas, tais festas configuravam-se, na segunda metade do século XIX, como uma opção frequente de lazer dos habitantes da região da Saúde.

Algo havia mudado, porém, nos primeiros anos da República. Se, nas últimas décadas do Império, aquelas práticas podiam ser vistas pelo Delegado Distrital de Santana como algo "muito antigo, sempre tolerado por todos os chefes de polícia e subdelegados", o controle e vigilância da polícia republicana

\footnotetext{
${ }^{26}$ Cf. Maria Cecília Velasco e Cruz, "Tradições negras na formação de um sindicato: Sociedade de Resistência dos trabalhadores em Trapiche e Café, Rio de janeiro, 1905-1930", Afro-Ásia, n. 24, 2000, p. 243-290. A autora demonstra no artigo que, entre 1890 e 1904, os negros e mestiços constituíam 60,5\% dos estivadores presos na Casa de Detenção.

${ }^{27} \mathrm{Cf}$. Agenor Miranda Rocha, As nações Kêtu: Origens, ritos e crenças. Os candomblés antigos do Rio de Janeiro, Rio de Janeiro, Mauad, 2000, p. 25.

${ }^{28} \mathrm{O}$ relato de João do Rio, publicado originalmente na Gazeta de Notícias em 1904, apareceu no ano seguinte no livro As religiões do Rio, Rio de Janeiro, Organizações Simões, 1951 (1905).

29"A Polícia”, O Paiz, 20 de dezembro de 1886.

30. Arquivo Geral da Cidade do Rio de Janeiro, “Diversões particulares. Pedidos de licença (1833-1908)”, 42.3.14.
} 


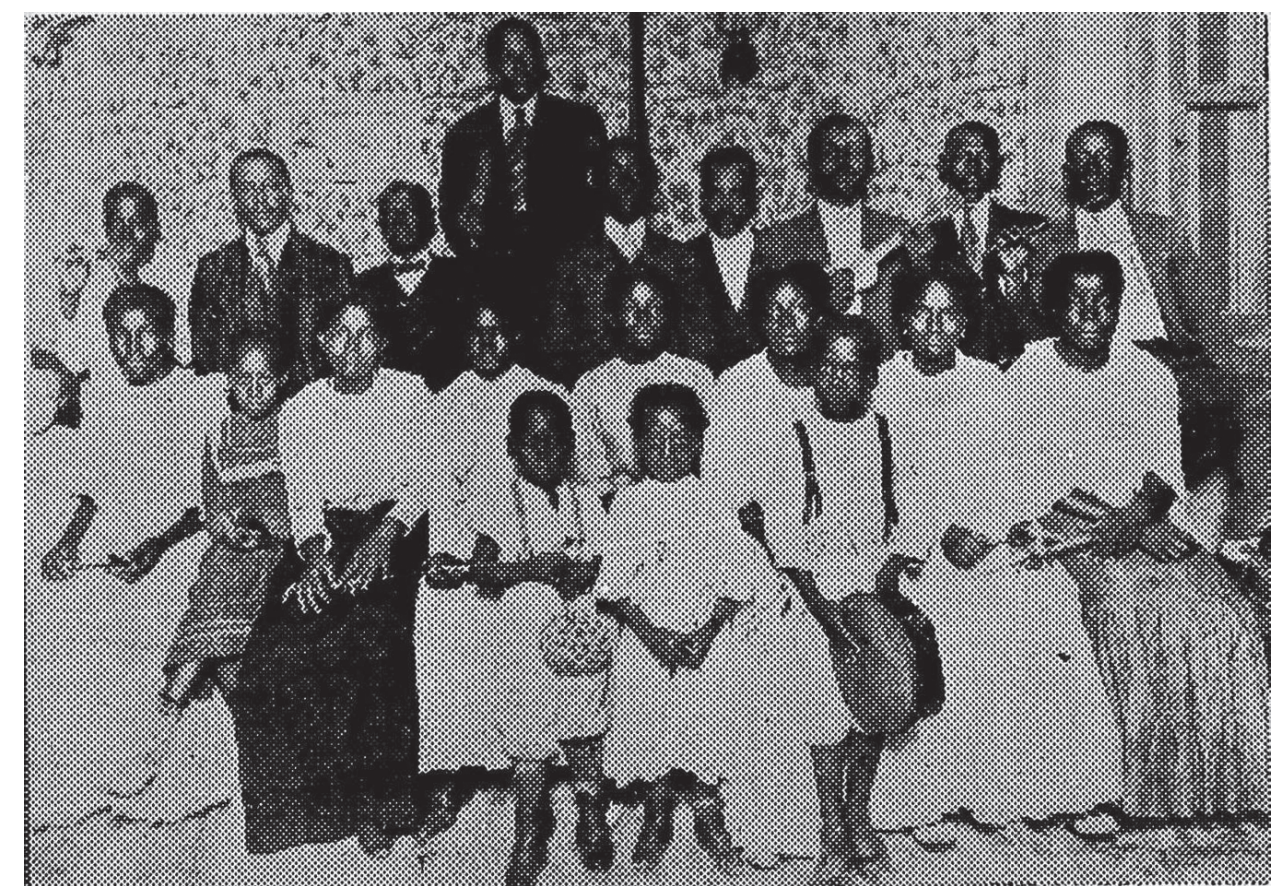

"O Macaco é Outro" (REVISTA DA SEMANA 18 de fevereiro de 1911),

grupo carnavalesco.

passariam a atingi-las com muito mais força. Tais tentativas de controle levaram a um processo de institucionalização desses festejos por parte de seus promotores, que passaram a tentar fugir da perseguição policial por meio de licenças de funcionamento concedidas aos clubes dançantes e carnavalescos por eles organizados. Esse foi um processo iniciado ainda em 1886, quando foi fundado no bairro o "Club da Saúde". Definido pelo jornal como "uma sociedade modesta e distinta", ele tinha a finalidade de promover bailes mensais para os seus sócios. ${ }^{31}$ Foi o sucesso desse modelo que levou à criação no bairro, a partir dos primeiros anos da República, de vários outros clubes do gênero. É o caso do Rei de Ouros, fundado na Pedra do Sal em 1894 por um grupo de negros de origem baiana, com sede no Morro da Conceição; do Prazer da Providência, que, no ano seguinte, conseguia sua licença de funcionamento; ou da Sociedade Dançante Carnavalesca Jardineira. ${ }^{32}$

Diferentes em suas cores, cantos e sedes, essas sociedades dançantes da Saúde tinham a aproximá-las um mesmo tipo de composição e de lógica recreativa. Esta se expressa, de maneira clara, em uma delas chamada "Rosa Branca", com sede na Rua dos Cajueiros. Em crônica publicada em meio ao carnaval de 1905, João do Rio conta ter sido procurado por um de seus componentes, que conhecia de outros tempos, para conseguir "uma licença" para o clube..$^{33}$ Além

${ }^{31} \mathrm{Cf}$. O Paiz, 17 de julho de 1886 e 21 de maio de 1887.

${ }^{32}$ Cf. Nireu Cavalcanti, “Memórias de alegria: O Rio de Janeiro na folia dos ranchos (1893-1911)", In: Icléia Thiesen et al., Vozes do Porto: memória e história oral, Rio de Janeiro, DPA/Unirio, 2005, p. 93; O Paiz, 24 de fevereiro de 1895; e Jota Efegê, Ameno Resedá, o rancho que foi escola, Rio de Janeiro, Letras e Artes, 1965, p. 76-81

33João do Rio, "Afoché", Gazeta de Notícias, 2 de março de 1905. 
de mostrar a importância de tal licença de funcionamento para essas sociedades, o caso dá motivo para que o cronista visite o clube em questão, no qual aconteceria, naquele dia, um ensaio carnavalesco com "um sarau e o samba na sala dos fundos". Ao adentrar os modestos salões do clube, ouviu as danças e cantos "ao som dos pandeiros, dos atabaques". Mostrou-se logo impressionado com a organização administrativa do clube, cuja ampla diretoria zelava pelo bom andamento dos festejos. "Quase sempre estes cargos importantes são ocupados por auxiliares de feitiçaria”, comenta, a atestar a proximidade entre as práticas religiosas e festivas entre esses trabalhadores de ascendência africana. Ainda que os membros do clube possam, por vezes, não diferenciar as atividades dançantes daquelas de cunho carnavalesco ou religioso, o informante do cronista explica a ele que "a licença é sempre pedida para uma sociedade dançante", instituição cuja legitimidade era atestada por crônicas como a de Bilac.

O clube configurava-se, com isso, como um local legítimo de expressão dos costumes e práticas compartilhados por seus sócios, expostos de modo diferenciado em espaços diversos. "Quem quer sambar vai para os fundos e quem gosta de bailes fica polcando na frente", explicava o cronista. A diferença entre os dois espaços era clara para o cronista: enquanto o samba teria sua "origem na dança dos sertões da África Central", o baile seria "muito mais suave": "dança-se de vagar, ao som de um flautim e de um cavaquinho" - em um tipo de musicalidade que, se guardava sinais da musicalidade de origem africana, era entendida pelos membros do clube como uma mistura clara entre esta e outras formas musicais de origem europeia. Desse modo, "os negros e os mulatos" que ele via no clube tinham naquele tipo de associação um espaço próprio de diversão, no qual tanto buscavam legitimidade para suas práticas costumeiras quanto tratavam de misturá-las a novos modismos e influências que passavam a incorporar como seus.

Mais do que social, era, assim, étnica a ligação de muitos desses pequenos clubes do bairro. Por mais que a Saúde estivesse longe de constituir qualquer tipo de território exclusivamente negro, abrigando muitos trabalhadores de outras procedências e perfis étnicos, ${ }^{34}$ o modelo adotado por clubes como aqueles baseava-se no compartilhamento e defesa de alguns símbolos identitários de matriz africana. É o que sugere, em 1914, a disputa que separaria os sócios dos Heróis Brasileiros, que funcionava na Gamboa desde 1900, daqueles do Retiro da América, fundado na Saúde em $1888 .{ }^{35}$ No carnaval de 1914, alguns sócios deste mandam ao jornal A Época versos intitulados "Sentido Negrada", em que explicitam suas diferenças com o rival. Sugerindo ter recebido deles "um cachinho de banana", referência abertamente racista à cor de seus componentes, respondiam aos "mondrongos dos Heróis" (ou seja, aos desengonçados componentes do clube rival) no mesmo tom. "Heróis, que avacalhação/

\footnotetext{
${ }^{34}$ Segundo os dados do censo realizado em 1906 no Distrito Federal, o distrito de Santa Rita, no qual estava situado o bairro da Saúde, contava naquele momento com 38,28\% de habitantes estrangeiros. Cf. Recenseamento do Rio de Janeiro realizado em 20 de setembro de 1906, Oficina da Estatística, Rio de Janeiro, 1907, p. 123.

${ }^{35} \mathrm{Cf}$. Arquivo Nacional, IJ6 692; e A Época, 17 de janeiro de 1913.
} 
Brasileiros vocês não são", cantavam eles em verso, a sugerir a falsidade do nome que tentavam se atribuir. "Coitados dos patrícios/ Acabam lá no hospício", completavam os membros do Retiro da América, em diferenciação por meio da qual tentavam associar a cor de sua pele à marca da nacionalidade. ${ }^{36}$ Era como um meio de expressar a força e orgulho de sua identidade que se articulavam trabalhadores como aqueles que compunham o Retiro da América.

Essa lógica alimentaria a grande explosão do associativismo dançante na Saúde verificada nos primeiros anos do século XX - que fazia com que, naquele ano de 1913, mais de 15 clubes do gênero já pudessem ser encontrados no bairro. ${ }^{37}$ Dentre eles estava, desde 1906, o Anjos da Meia Noite, que já no ano seguinte passou também a tentar garantir sua legitimidade por meio do pedido anual de licença de funcionamento enviada ao Chefe de Polícia. ${ }^{38}$ Ao se apropriarem do título de uma peça teatral de grande popularidade no Rio de Janeiro do início do século XX, cujo sucesso se devia ao gosto do público de baixa renda pelos truques cênicos e pelos enredos mirabolantes, ${ }^{39}$ os sócios do clube davam uma primeira indicação sobre sua composição. Esta seria atestada pela lista de seus fundadores e diretores — dentre os quais figurava em 1908 o estivador Leonardo Machado, que se apresentava então como seu vice-presidente. ${ }^{40}$ Formado por trabalhadores de baixa renda como ele em um bairro majoritariamente habitado por negros e pardos, o clube representava mais um dos espaços de lazer formados no período por tais sujeitos.

Era, assim, na encruzilhada entre práticas costumeiras e modismos elegantes, como o da febre dançante, que os membros de clube como o Anjos da Meia Noite tratavam garantir seu espaço e legitimidade em meio aos primeiros tempos da República - o que os colocava como parte daquele movimento de criação de uma identidade para o bairro identificada por Bilac meses antes de sua fundação. Por meio desses caminhos, seus sócios conseguiram ver afirmadas, nos primeiros anos do século XX, certas marcas identitárias próprias, com fortes traços negros reconhecíveis pelo cronista e seus leitores. Restava saber quais seriam as consequências do sucesso dessa operação simbólica.

\section{A cidadania em processo}

A partir do momento em que esses pequenos clubes da Saúde fixaram a imagem mestiça e negra projetada pela crônica de Bilac, não seria mais tão fácil seu caminho de afirmação. Ainda que formalmente organizadas para fugir à perseguição policial, nem sempre essas sociedades conseguiram alcançar esse intento. Com um funcionamento regular supostamente garantido pela

36"C.C. Retiro da América", A Época, 20 de fevereiro de 1914.

${ }^{37}$ Arquivo Nacional, GIFI 6C 432.

${ }^{38}$ Arquivo Nacional, GIFI 6C 213.

39"Teatro Recreio", Correio da Manhã, 20 de outubro de 1902. Sobre a popularidade da peça e seus motivos, ver João Roberto Faria, "Machado de Assis - tradutor de teatro", Machado de Assis em linha, ano 3, n. 6, dez. 2010, p. 56.

${ }^{40} \mathrm{Cf}$. "Vida Operária”, Correio da Manhã, 27 de março de 1906. 
concessão da licença anual, elas conviviam cotidianamente com a ameaça de sua cassação por parte da polícia, o que impediria a continuidade de suas atividades. Se tal possibilidade se colocava durante todo o período de existência desses pequenos clubes, no início da década de 1910 parecia se tornar mais evidente a tensão entre a polícia daquele distrito e as pequenas sociedades recreativas formadas no bairro.

Os próprios sócios do Anjos da Meia Noite seriam testemunhas do início dessa mudança de postura. Depois de funcionar regularmente em seus primeiros anos de atividade, eles foram surpreendidos no dia 2 de janeiro de 1910 por um pedido encaminhado ao Chefe de Polícia pelo Delegado do distrito, Benedicto da Costa Ribeiro. Ele solicitava que não fosse mais concedida a "licença para o funcionamento desta sociedade" em virtude de sua composição, "visto ser ponto de reunião de meretrizes de baixa esfera, desordeiros e ladrões". Como resultado, o Chefe de Polícia providenciou, no dia seguinte, "no sentido de não ser permitida licença para o funcionamento dessa sociedade". ${ }^{41}$ Por mais que nos anos anteriores a licença tivesse sido concedida sem problemas, a partir daquele momento o quadro social do clube começava a ser colocado sob suspeita, formado que ele era por membros das chamadas "classes perigosas".42

Os anos que se seguiram mostrariam que não se tratava de um acaso. De forma sistemática, clubes dançantes da Saúde e de outros bairros habitados por trabalhadores passaram a enfrentar situações semelhantes, com autoridades policiais diversas lançando sobre eles a sombra da suspeita e tentando obstaculizar seu livre funcionamento. Quando a Sociedade Carnavalesca Triunfo dos Beija Flores, com sede no Morro da Providência, pediu em fevereiro de 1912 sua licença de funcionamento ao Chefe de Polícia, seus sócios foram vítimas da mesma lógica que havia atingido os membros do Anjos da Noite. Antes mesmo de o processo chegar ao respectivo distrito, Arthur Rodrigues da Silva, o Inspetor do Corpo de Segurança ao qual cabia dar um primeiro parecer sobre tais pedidos, informava "ser esta sociedade composta de desordeiros e vagabundos, não se encontrando pessoa alguma que abonasse a conduta dos mesmos". Chamado a opinar, o Delegado do distrito encaminhou o caso a um de seus comissários, que mostrou ter opinião diversa: ao conhecer no local os componentes do clube, esclareceu ser ele composto por "homens do trabalho morigerados e com domicílio certo, não havendo inconveniente algum na aprovação de seus estatutos e em ser-lhes concedida a licença que pede". O processo retornou então ao Inspetor do Corpo de Segurança, que voltou à carga denunciando que "o presidente desta sociedade" seria "desertor da Força Policial”, tendo sido, por isso, preso. Já o fiscal do clube, que se declarara "empregado do Armazém da Estação Central", só apareceria ali "uma ou duas vezes por mês", não sendo possível, por isso, "dizer que tem emprego".

\footnotetext{
${ }^{41}$ Arquivo Nacional, GIFI 6C 367.

42Sobre a associação entre "classes pobres" e "classes perigosas" no Rio de Janeiro do período, ver Sidney Chalhoub, Cidade febril: cortiços e epidemias na Corte Imperial, São Paulo, Companhia das Letras, 1996.
} 
$\mathrm{O} 2^{\circ}$ Fiscal, por sua vez, teria sido demitido de seu emprego no setor de cargas da Leopoldina Railway "por ser vadio" - assim como o procurador do clube, que teria sido demitido "por ter sido pego em flagrante furtando vinho de um barril ali em depósito". ${ }^{43}$ Perseguido pelo caráter precário e instável das relações de trabalho que seus sócios conseguiam estabelecer, o clube precisou, assim, desligá-los para conseguir a necessária licença policial, adaptando-se às normas do controle oficial.

Casos como esses, que se repetiam aos montes no bairro, ${ }^{44}$ mostravam que era o perfil social dos membros de clubes como o Anjos da Noite que justificava a perseguição das autoridades policiais sobre eles. A diferenciação feita entre os clubes pela polícia por conta de seu perfil social era perceptível mesmo para os contemporâneos. Em nota de 1916 sobre os constantes "conflitos nos clubes de jogo chics", um redator do jornal A Noite comenta que "se fossem clubes pequenos, seriam varejados, presa a diretoria, cassada a licença", coisas que raramente aconteciam nos clubes elegantes. ${ }^{45} \mathrm{~A}$ cassação da licença enfrentada pelos Anjos da Meia Noite em 1910 aparecia, assim, como o início de um movimento de repressão aos pequenos clubes dançantes formados por trabalhadores, por meio do qual a polícia tentava controlar a crescente onda associativa verificada em bairros como a Saúde.

Sem se colocarem como vítimas passivas da ação policial, os sócios do Anjos da Meia Noite trataram de iniciar uma elaborada estratégia de reação para garantir o funcionamento do clube. Ela consistiu, antes de mais nada, na tentativa reverter a decisão, de modo a conseguir de volta sua licença de funcionamento. Para isso, o clube tratou de excluir do seu quadro, ao menos formalmente, "os antigos sócios de conduta duvidosa" que haviam servido de justificativa para a negação da licença, como atestava em 1912 o parecer do comissário de polícia local. "Convém ainda notar que muitos associados possuem carteira de identidade", completava o mesmo comissário, ressaltando que os "empregados no comércio, artistas, empregados no cais e polícia do porto" que compunham o clube teriam então "residência e profissão conhecida". Como resultado, o clube conseguiu reaver sua licença em abril de 1912, apesar do parecer ainda contrário do Inspetor de Segurança. ${ }^{46}$

Além dessa reação imediata, os sócios do clube trataram também de tentar se precaver contra novos incidentes do gênero de forma mais permanente. Para isso, resolveram, em março de 1910, inscrever seus estatutos no registro civil, publicando um extrato dele no Diário Oficial, ${ }^{47}$ o que não era necessário para clubes recreativos como o Anjos da Meia Noite. Ao fazerem isso, trataram de amparar-se em uma lei promulgada em 1893 para regular "a organização das

\footnotetext{
${ }^{43}$ Arquivo Nacional, Documentação de Polícia, p. 416, cx. 5553.

${ }^{44}$ Conferir os casos do Triunfo dos Beija-Flores, que seria composto por "pessoas desempregadas, vagabundos e desordeiros"; e dos Couraceiros do Inferno, "frequentado pela escória social", motivo pelo qual o delegado local julga importante fechá-lo "como medida de ordem social", Arquivo Nacional, GIFI 6C 479 e Documentação de Polícia, P. 489, cx. 5668

45"O conflito no Palace Club", A Noite, 29 de outubro de 1916.

${ }^{46}$ Arquivo Nacional, GIFI 6C 367.

47“"Sociedades civis - Club Dançante Familiar Anjos da meia Noite”, Diário Oficial, 10 de março de 1910, p. 1786.
} 
associações que se fundarem para fins religiosos, morais, científicos, artísticos, políticos ou de simples recreio". Em seus primeiros artigos, tal lei estipulava que as associações criadas com tais finalidades poderiam "adquirir individualidade jurídica" ao inscrever seu contrato social ou seus estatutos "no registro civil da circunscrição onde estabelecerem a sua sede". ${ }^{48} \mathrm{O}$ resultado era que tais associações passariam a gozar de "capacidade jurídica, como pessoas distintas dos respectivos membros, e podem exercer todos os direitos civis relativos aos interesses do seu instituto". Frente ao arbítrio dos agentes policiais, os sócios do Anjos da Noite buscaram na legislação republicana uma garantia para o seu regular funcionamento, que independesse da opinião de delegados ou inspetores sobre seus associados. Tratava-se, assim, ao mesmo tempo, de uma estratégia jurídica e de um ato político, cujo sentido era claro: a garantia da liberdade de manifestação de suas próprias práticas e costumes, expressos nas atividades rotineiras do clube.

\section{Membros de vários outros clubes da região portuária mostravam também articular o associativismo dançante e a luta politica em suas experiências}

À primeira vista, pode surpreender o fato de que trabalhadores de baixa renda como aqueles que compunham o clube, cuja finalidade era meramente recreativa, se mostrassem tão atentos às brechas da legislação que podiam ajudar a construir sua legitimidade. Esse estranhamento não resiste, porém, a um olhar mais aproximado sobre seus componentes. Distantes da imagem alienada e passiva projetada por parte de muitos militantes operários do período sobre os componentes de clubes como aqueles, ${ }^{49}$ os sócios do Anjos da Meia Noite mostravam não ver contradição entre a busca do lazer e a participação mais efetiva no enfrentamento político e social. Não por acaso, dentre seus fundadores, estava o foguista David Francisco Candido, que pelo menos desde 1904 era um ativo participante do Centro Geral dos Foguistas e que em 1912 mostrava-se ainda envolvido com propostas de "união da classe".50 Do mesmo modo, quando o clube decidiu oficializar seus estatutos, tinha como presidente o estivador Leonardo Machado, desde 1906 um ativo participante da União dos Operários Estivadores - sociedade cujo endereço ficava no mesmo Largo do Depósito em que estava sua sede, de cuja diretoria Leonardo passou a fazer parte a partir de $1908 .{ }^{51}$ Como líderes de categorias de forte presença negra,

\footnotetext{
48“Lei no 173, de 10 de setembro de 1893”, Disponível em: <http://www2.camara.leg.br/legin/fed/lei/1824-1899/ lei-173-10-setembro-1893-540973-publicacaooriginal-42519-pl.html>. Acesso em 5 fev. 2013.

${ }^{49} \mathrm{Cf}$. Leonardo Pereira, "The Flower of the Union: Leisure, race and social identity in Bangu, Rio de Janeiro (1904-1933)", Journal of Social History, vol. 46, n. 1, fall 2012, p. 154-169.

${ }^{50} \mathrm{Cf}$. "Vida operária”, Correio da Manhã, 29 de março de 1904 e "Coluna operária”, A Época, 9 de dezembro de 1912.

51“Vida operária”, Correio da Manhã, 27 de março de 1906 e 2 de setembro de 1908.
} 
esses sujeitos mostravam que, para parcelas do movimento operário mais distantes do modelo de ação política comum a imigrantes de origem europeia, a busca do lazer e a atuação política pareciam articuladas em uma mesma experiência, que estava longe de se poder definir pela marca da alienação.

Os sócios do Anjos da Meia Noite não constituíam um caso isolado. Como eles, os membros de vários outros clubes da região portuária mostravam também articular o associativismo dançante e a luta política em suas experiências. Ao resolverem, em setembro de 1906, fundar a Sociedade União dos Foguistas para lutar por seus direitos, os trabalhadores nas caldeiras buscaram abrigo justamente na sede do Retiro da América. ${ }^{52}$ No caso dos Anjos da Noite, no entanto, essas ligações pareciam ainda mais evidentes. Quando, no final de 1912, Leonardo Machado deixou a presidência do clube, assumiu seu lugar Victorino Gonçalves, descrito por um comissário de polícia como um estivador "que goza de boa reputação pelo seu amor ao trabalho e por sua conduta".53 Como Leonardo, ele era participante ativo do movimento operário carioca, tendo atuação destacada na Liga do Operariado do Distrito Federal — da qual chegou a ocupar a presidência naquele ano de $1913 .{ }^{54}$ Por mais que ele pudesse ter diferenças políticas ou administrativas com o antigo presidente, ${ }^{55}$ mostrava, assim, compartilhar com ele uma mesma perspectiva em relação ao associativismo dançante, cuja importância não era deixada de lado em favor de outros espaços de articulação social supostamente mais relevantes.

Não era de se estranhar, por isso, que os sócios do Anjos da Noite se mostrassem tão atentos em 1910 ao sentido político da cassação de sua licença. Para evitá-la, elaboraram uma estratégia na qual mostravam não ver uma diferença essencial entre uma associação com fins recreativos e outras de caráter político ou sindical - tentando garantir o funcionamento daquela pelas mesmas regras e leis em que se apoiavam para amparar o funcionamento destas.

Era essa a lógica que se explicitaria, a partir de maio de 1913, quando um pequeno conflito ocorrido no clube serviu de pretexto para uma nova tentativa do Chefe de Polícia de sustar seu funcionamento. Na noite de sábado, dia 24 de maio, os Anjos da Meia Noite realizaram, como de costume, um concorrido baile. Nos salões cheios de sua sede, os sócios e demais convidados dançavam animadamente em pares ao som dos choros e polcas tocadas por "uma charanga" ${ }^{56}$ Dentre eles, estavam Henrique Rodrigues da Fonseca, um ladrilheiro que exercia então o cargo de $2^{\circ}$ Fiscal do clube, ${ }^{57} \mathrm{e}$ um certo Joaquim Barbosa, seu consócio, que o repórter do Jornal do Brasil se limitou a definir como um

${ }^{52} \mathrm{Cf}$. "Sociedade União dos Foguistas", A Época, 27 de setembro de 1917. Sobre a composição e sede do Retiro da América em 1912, ver Arquivo nacional, GIFI 6C 367.

${ }^{53}$ Arquivo Nacional, GIFI 6C 367.

54"Coluna Operária”, A Época, 3 de março de 1913 e 24 de abril de 1913.

${ }^{55} \mathrm{Em}$ nota paga publicada no Jornal do Brasil, em 17 de maio de 1913, para anunciar um de seus bailes, Victorino Gonçalves cobrava "ao Sr. ex-Presidente" do clube que, no prazo de cinco dias, aparecesse para "prestar as suas contas, conforme prometeu verbalmente", sendo que, ao fim deste prazo, seria "publicado o nome do mesmo, nos jornais" “S.D. Anjos da Meia Noite", Jornal do Brasil, 17 de maio de 1913.

56"Tentativa de assassinato", O Imparcial, 26 de maio de 1913.

57É o que se afirma no pedido de licença encaminhado pelo clube à polícia em 1912. Arquivo Nacional, GIFI 6C 432; e "S.D. Anjos da Meia Noite", Jornal do Brasil, 17 de maio de 1913. 
"pardo" ${ }^{58}$ Sem respeitar as regras de comportamento definidas pelos estatutos do clubes, Barbosa passou a assediar com insistência uma mulher que seria o par de Henrique ao longo da noite. Tal assédio incomodou Henrique, que foi tirar satisfações com o galanteador, dando início a um desentendimento entre ambos. Inicialmente controlado com a intervenção do diretor de salão do clube, que disse a eles não ser permitido "discutir dentro do salão", o caso teria desdobramentos por volta das quatro hora da madrugada, quando o baile começava a esfriar. Ao saírem do clube, encontraram-se novamente os dois no Largo do Depósito, no qual se localizava sua sede. O resultado foi um confronto físico no qual a perna de Joaquim Barbosa foi baleada por Henrique, que acabou também ferido em sua tentativa de fuga. ${ }^{59}$

\section{Tais trabalhadores faziam de suas práticas dançantes um meio de lutar por liberdade e direitos, em favor da República que queriam}

Diante do ocorrido, a diretoria do clube se apressou em negar que o desentendimento tivesse relação com o baile ou que houvesse o crime se desencadeado em sua sede. Ao comparecer espontaneamente à sede do Jornal do Brasil para prestar esclarecimentos, Deocleciano Silva, Primeiro Secretário da associação, explicava que "o baile terminou às 3 e 40 minutos da madrugada e o conflito aludido deu-se às 4 e 50 minutos, isto é, uma hora quase depois de fechado o club". Do mesmo modo, afirmava que "a desordem foi promovida na rua, sem ter havido durante o baile a menor alteração da ordem" ${ }^{\prime 60}$ De nada adiantaram, porém, tais explicações. Frente à grande cobertura que o caso ganhou na imprensa da capital federal, o Chefe de Polícia expediu ao Delegado do distrito a ordem de cassação da licença de funcionamento da sociedade, determinando o "fechamento da sede social" e "impedindo por meio de seus agentes e da força pública" que o clube continuasse a funcionar. ${ }^{61}$

A primeira reação da diretoria do clube, tomada logo após serem informados "pelo Sr. Dr. Delegado do $2^{\circ}$ Distrito Policial e noticias dos jornais que se publicam nesta capital" sobre a determinação de fechamento do clube, foi escrever, no dia 5 de junho, ao $2^{\circ}$ Delegado Auxiliar, responsável pelas diversões públicas, solicitando a revogação da "referida ordem". ${ }^{62}$ No dia seguinte, este dá um despacho curto à solicitação - "dirija-se a quem de direito" — que

\footnotetext{
58"Quem não trouxe... - Depois do baile - Ciúme sanguinário", Jornal do Brasil, 26 de maio de 1913.

59"Um turumbamba no Anjo da Meia Noite”, O Paiz, 26 de maio de 1913. Embora variando em alguns pontos, notícias sobre o conflito encontram-se também em "Tentativa de morte", A Época, 26 de maio de 1913; "Na sede do Club Anjo da Meia Noite", Correio da Manhã, 26 de maio de 1913.

60" Quem não trouxe...", Jornal do Brasil, 27 de maio de 1913.

${ }^{61}$ Arquivo Nacional. Fundo Supremo Tribunal Federal (BV). BV.4624. - Série Habeas Corpus - Clube Dançante Familiar Anjos da Meia Noite (1913), fl. 2.

62/dem, Ibidem, fl. 6.
} 
sugeria ser aquele um pedido a ser encaminhado ao próprio Chefe de Polícia, Edwiges de Queiroz. É o que faz o presidente do clube no dia 7 daquele mês, em ofício em que reproduzia a mesma argumentação apresentada antes ao seu auxiliar. Nela, explicava serem "as associações que estão sujeitas a fiscalização e licença da polícia [...] somente aquelas que não adquirirem personalidade jurídica", o que não seria mais o caso dos Anjos da Meia Noite. Frente à ilegalidade que percebiam nesse ato, apelavam ao Chefe de Polícia para "revogar a referida ordem, certo de que assim se procedendo evitar-se-á os remédios jurídicos que cabem ao caso ocorrente".63

Foi o indeferimento sumário do pedido pelo chefe de polícia, lavrado no dia 14 de junho, que levou os sócios do clube a cumprirem a promessa expressa ao fim da petição, buscando na justiça a reparação da situação. É o que fazem poucos dias depois, em 20 de junho, no pedido de habeas corpus originariamente entregue à Corte de Apelação. Voltavam nele a reclamar do "ato violento, arbitrário e abusivo de poder do Sr. Dr. Chefe de Polícia”, que não encontraria nenhum amparo nas "disposições de regulamentos e avisos preventivos da polícia e referentes ao funcionamento de associações civis" que tinham personalidade jurídica, como era o caso do Anjos da Meia Noite. Frente ao juízo, no entanto, iam ainda mais longe em sua argumentação. Apelando para o parágrafo $8^{\circ}$ do artigo 72 da Constituição republicana - que determinava que "a todos é lícito associarem-se e reunirem-se livremente e sem armas; não podendo intervir a polícia, senão para manter a ordem pública" - diziam ser direito de "qualquer associação civil" ficar livre "dos abusos e violências da polícia, no tocante ao livre funcionamento, independentemente de licença para exercer fins do seu instituto". Por tal motivo, pediam que fosse concedido o habeas corpus em favor do clube para ele

poder exercer livremente todos os direitos civis relativos aos interesses de seu intuito, como quer e manda a lei [...], independentemente para isso de qualquer licença da polícia e sem perturbação ou coerção de espécie alguma de qualquer autoridade policial e seus agentes. ${ }^{64}$

Mais uma vez, no entanto, os sócios do clube viram frustradas suas expectativas. Por questões técnicas, a Corte de Apelação julgou "incabível o recurso" e "não tomou conhecimento do pedido julgado". ${ }^{65}$ Foi assim, como uma tentativa final de fazer valer suas aspirações, que os sócios do clube recorriam, no próprio dia 20 de junho, ao "Venerando Supremo Tribunal Federal”, ao qual caberia, "de fato de direito, de jurisprudência", a coragem de garantir aos sócios de clubes como aquele seus direitos frente à omissão das outras esferas da justiça. Caberia, assim, à Corte Suprema, nessa lógica, fazer cessar o "constrangimento ilegal que sofre o Club Dançante Familiar Anjos da Meia Noite”. Para

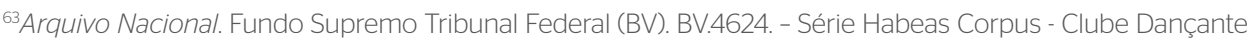
Familiar Anjos da Meia Noite (1913), fl. 5.

64/dem, Ibidem, fl. 2.

65/dem, Ibidem, fl. 7; e "Justiça local - Corte de Apelação", O Paiz, 22 de junho de 1913.
} 
amparar tal pedido, apelavam ainda para as determinações da Lei que regulava o instituto do habeas corpus, de 1871 - em especial, de um de seus artigos que definia que, reconhecido pela autoridade o "constrangimento ilegal, abuso de autoridade ou violação flagrante da lei", caberia a ela "ordenar ou requisitar a responsabilidade da que assim abusou". ${ }^{66}$ Para além da concessão do habeas corpus, os sócios do clube cobravam, assim, do Supremo Tribunal Federal a punição ao Chefe de Polícia responsável pelo arbítrio que lhe deu origem, de modo a reestabelecer os princípios constitucionais da ordem republicana.

Frutos diretos da estratégia adotada pelos sócios do Anjos da Meia Noite desde 1910 para fugir da perseguição policial, os argumentos então apresentados pelo clube para solicitar o habeas corpus deixavam explícito o sentido político de sua atuação. Em um momento no qual os trabalhadores cariocas passavam a apelar com regularidade ao Supremo Tribunal Federal para tentar ver garantidos seus direitos, ${ }^{67}$ os sócios do clube mostravam o sentido amplo que atribuíam ao seu pedido, que estava longe de se esgotar no problema específico que lhe deu origem. Do ponto de vista por eles expresso, a garantia da continuidade das atividades do clube era uma questão ligada à própria busca de direitos por parte de trabalhadores como os que o compunham, expressa na possibilidade de continuarem a praticar os costumes dançantes que os singularizavam.

A polícia pratica todos estes abusos, estas ilegalidades, esquecendo-se de que constitucionalmente ninguém pode ser obrigado a fazer ou deixar de fazer alguma cousa senão em virtude da lei,

dizia o advogado deles no recurso entregue à Corte de Apelação. ${ }^{68}$ Era assim, utilizando-se das brechas do próprio aparato jurídico criado para garantir e perpetuar sua exclusão - assim como haviam feito, no século anterior, muitos dos seus antepassados que buscaram brechas de autonomia em meio a uma sociedade escravista ${ }^{69}$ - que tais trabalhadores faziam de suas práticas dançantes um meio de lutar por liberdade e direitos, em favor da República que queriam.

Essa era, porém, uma luta árdua e prolongada, ainda distante de ter um fim. Frente às colocações do advogado do clube, os juízes do Supremo optaram por "converter o julgamento em diligência, a fim de requisitar-se informações ao Dr. Chefe de Polícia deste Distrito sobre o alegado na referida petição". Este respondeu, poucos dias depois, reiterando ter sido a licença cassada a pedido do Delegado do distrito. Além de citar o conflito ali havido no dia 25 de maio, dizia ser o clube um "ponto de indivíduos perigosos e de má nota, que cobravam entrada para dançar sem que para isso estivessem legalmente habilitados".

\footnotetext{
${ }^{66}$ Arquivo Nacional. Fundo Supremo Tribunal Federal (BV). BV.4624. - Série Habeas Corpus - Clube Dançante Familiar Anjos da Meia Noite (1913), fl. 12.

${ }^{67}$ Conferir, a tal respeito, Gladys Sabina Ribeiro, "Cidadania e luta por direitos na Primeira República: analisando processos da Justiça Federal e do Supremo Tribunal Federal", Tempo, n. 26, jan. 2009, p. 101-117.

${ }^{68}$ Arquivo Nacional. op cit., fl. 3.

${ }^{69} \mathrm{Cf}$. Elciene Azevedo, O direito dos escravos: Lutas jurídicas e abolicionismo na província de São Paulo, Campinas, Ed. da Unicamp, 2010. Ver, ainda, em perpectiva semelhante, E.P. Thompson. Senhores e caçadores. A origem da Lei Negra, Rio de Janeiro, Paz e Terra, 1987 [1975].
} 
Ainda que não apresentasse nenhuma evidência que amparasse suas alegações, essas foram então acolhidas pelos juízes do Supremo. Sem enfrentar o ponto central do argumento expresso no pedido, estes decidem negar o provimento do recurso sob a alegação de que o habeas corpus teria apenas o fim de "garantir a liberdade individual", não valendo para um clube dançante. Mesmo que o recurso fosse admissível, porém, a decisão do tribunal afirma que "as informações prestadas demonstram que a autoridade policial agiu dentro da esfera de suas atribuições legais", não se justificando, por isso, a concessão do pedido. ${ }^{70}$

O resultado do processo demonstrava, à primeira vista, que o recurso à lei não era ainda um meio efetivo de conquista de direitos para sujeitos como os sócios do Anjos da Meia Noite. Mais efetivo que este era, naquele momento, o caminho trilhado por associações do gênero que tentavam garantir sua sobrevivência por dentro das malhas do paternalismo, agregando em sua diretoria comerciantes e autoridades dos bairros em que foram formados para proteger-se do arbítrio policial. ${ }^{71}$ Ainda assim, a luta travada pelos membros do clube demonstrava que os trabalhadores que o formavam estavam atentos às possibilidades de liberdade e autonomia que lhes eram possíveis dentro da nova ordem republicana. Colocados frente a uma ordenação jurídica forjada para excluí-los, esses sujeitos trataram de achar formas próprias de conquista de espaço. Ao obrigarem os juízes do Supremo Tribunal Federal a explicitar as contradições da ordem constitucional criada pela República, ajudavam a explicitar a arbitrariedade daquele sistema político - contribuindo, com isso, para minar suas bases ideológicas. Foi cada vez mais difícil à polícia, por isso, coibir o funcionamento de associações como essas - em especial quando seus sócios somavam a defesa de seus direitos à busca do apoio e legitimidade de comerciantes brancos locais.

O caso ilumina, desse modo, a lógica política que se abrigava sob as formas costumeiras de associação comuns a muitos trabalhadores negros e pardos do período. Atuando a partir de formas próprias de luta por direitos já comuns para sujeitos como eles desde os tempos do Império - quando escravos se aproveitavam de seus espaços de lazer para afirmar e exercitar seus laços de identidade, fazendo das práticas da vida cotidiana uma forma própria de luta contra o domínio ao qual estavam submetidos,$-{ }^{72}$ os membros do clube tratavam de articulá-las a novos valores e lógicas aprendidas com os ideólogos dos novos tempos republicanos. Mostravam, com isso, o caráter dinâmico de sua luta, que estava longe de se esgotar no simples recurso à tradição. Evidenciavam-se, nesses caminhos, os limites de uma memória que tenta fazer deles vítimas passivas do discurso racial e político que serviu de base aos ideólogos da República.

\footnotetext{
${ }^{70}$ Arquivo Nacional. Fundo Supremo Tribunal Federal (BV). BV.4624. - Série Habeas Corpus - Clube Dançante Familiar Anjos da Meia Noite (1913), fls. 16-18.

${ }^{71} \mathrm{Cf}$. Leonardo A. de M. Pereira, "E o Rio dançou. Identidades e tensões nos clubes recreativos cariocas (19121922)", In: Maria Clementina Cunha (org.), Carnavais e outras f(r)estas, Campinas, Ed. da Unicamp, 2002, p. 419-444.

${ }^{72}$ Ver, por exemplo, Robert Slenes, “'Eu venho de muito longe, eu venho cavando': jongueiros cumba na senzala centro-africana", In: Silvia Hunold Lara; Gustavo Pacheco (orgs.). Memória do jongo: as gravações históricas de Stanley Stein, Rio de Janeiro, Folha Seca, 2008, p. 109-156.
} 